Jurnal Eksplorasi Akuntansi

ISSN : 2656-3649 (Online)

http://jea.ppj.unp.ac.id/index.php/jea/issue/view/16

\title{
PENGARUH KINERJA PEMERINTAH DAERAH DAN KARAKTERISTIK PEMERINTAH DAERAH TERHADAP VOLUNTARY GRAPHICS DISCLOSURE PADA PEMERINTAH KABUPATEN/KOTA DI INDONESIA TAHUN 2017
}

\author{
Atikah Wulandari' ${ }^{1}$, Salma Taqwa ${ }^{2}$ \\ ${ }^{1}$ Alumni Jurusan Akuntansi Fakultas Ekonomi, Universitas Negeri Padang \\ ${ }^{2}$ Jurusan Akuntansi Fakultas Ekonomi, Universitas Negeri Padang \\ *Korespondensi: atikahwlndr@gmail.com
}

\begin{abstract}
Abstrack: The objective of this study is to determine the effect of Local Government Performance, Level of Dependency, Local Government Location and Local Government Wealthy to Voluntay Graphics Disclosure on local government financial report in Indonesia. The sample of this study using the 231 districts/cities in Indonesia period of 2017. Sampling was done by using purposive sampling method. The type of data used is secondary data obtained from local government financial report (LKPD). The analytical method used is multiple linear regression analysis models were performed with SPSS 20.0. Results of regression testing showed that only level of dependency which effect negative and significant to voluntary graphics disclosure, while lokal government performance, local government location and local government wealthy not significantly effect to voluntary graphics disclosure on local government (districts/cities) in Indonesia period of 2017.
\end{abstract}

Keywords: Characteristics, Financial Statements, Local Government, Voluntary Graphics Disclosure

How to cite (APA $6^{\text {th }}$ style)

Wulandari, A \& Taqwa, S. (2019). Pengaruh Kinerja Pemerintah Daerah dan Karakteristik Pemerintah Daerah terhadap Voluntary Graphics Disclosure pada Pemerintah Kabupaten/Kota di Indonesia Tahun 2017. Jurnal Eksplorasi Akuntansi, 1(4), Seri C, 1896-1915.

\section{PENDAHULUAN}

Reformasi sistem pemerintahan yang mengubah system pemerintahan dari sentralisasi menjadi desentralisasi. Desentralisasi yaitu sistem pemerintahan yang menyerahkan segala kekuasaan dan kewajiban kepada daerah otonom untuk mengurus dan mengatur sendiri urusan pemerintahannya. Kebijakan mengenai desentralisasi dan otonomi daerah berlaku di negara berkembang termasuk Indonesia. Berdasarkan kebijakan otonomi daerah, pemda diwajibkan menyusun laporan pelaksanaan otonomi daerah salah satunya yaitu Laporan Keuangan Pemerintah Daerah (LKPD). Diamond (2002) menyatakan bahwa laporan keuangan bermanfaat bagi pengguna informasi khususnya dalam pengambilan keputusan.

Pemanfataan informasi laporan keuangan pemerintah daerah di Indonesia masih minim, dikutip dari berita neraca.co.id pada tahun 2017 yaitu acara International Sysmposium on the Future for Indonesian Government Financial Reporting, pada acara itu Wakil Menteri Keuangan 
RI menyatakan bahwa pemanfaatan informasi dalam laporan keuangan pemerintah daerah bagi pengambilan keputusan masih rendah. Oleh karena itu dibutuhkan pengungkapan atas laporan keuangan untuk memahami informasi yang terdapat di dalamnya. Pengungkapan dalam laporan keuangan dapat dikelompokkan menjadi dua, yaitu pengungkapan wajib (mandatory disclosure) dan pengungkapan sukarela (voluntary disclosure) (Kieso, Weygandt, \& Warfield, 2010). Khomsiyah (2003) menyatakan bahwa pengungkapan sukarela (voluntary disclosure) dapat memberikan nilai tambah bagi pemerintahan yang melakukannya yaitu telah mengungkapkan informasi yang tidak hanya seperti yang diisyaratkan oleh peraturan perundang-undangan.

Pengungkapan sukarela dapat dilakukan dengan berbagai metode salah satunya yaitu metode grafik. Paivio (1974) menjelaskan bahwa kemampuan manusia untuk mengingat pola visual (grafik) lebih baik dalam mengingat informasi secara tekstual dan tabulasi. Sehingga penyajian informasi dengan metode grafik lebih memudahkan para pengguna informasi untuk memahami informasi yang ada dalam laporan keuangan. Penyajian grafik dalam pengungkapan sukarela dipengaruhi oleh beberapa faktor yaitu kinerja pemda, tingkat ketergantungan pemda, lokasi pemda dan kekayaan pemda (Supriyanto dan Probohudono, 2015). Penelitian Dilla dan Janvrin (2010) menyatakan organisasi dengan kinerja yang baik akan menggunakan metode grafik dalam pengungkapan sukarela laporan keuangannya.

Tingkat ketergantungan pemda dipengaruhi oleh Dana Alokasi Umum (DAU). Semakin tinggi DAU yang diterima menunjukkan pemda tersebut tidak mandiri secara finansial. Setyowati (2016) menjelaskan semakin tinggi tingkat ketergantungan pemda maka semakin kecil kemungkinan pemda tersebut melakukan pengungkapan sukarela dengan metode grafik dalam LKPD. Lokasi pemda yang berbeda-beda menyebabkan perbedaan pada cara penyajian informasi dalam LKPD. Narulitasari (2016) menyatakan pemda di pulau Jawa lebih baik dalam menyajikan informasi dalam LKPD daripada pemda yang berada di luar pulau Jawa, hal ini disebabkan oleh faktor SDM, pendidikan dan ekonomi. Kekayaan pemda menggambarkan tingkat kemakmuran suatu daerah yang di proyeksikan melalui pendapatan asli daerah (PAD). Hilmi (2010) menjelaskan bahwa semakin besar kekayaan pemda maka semakin besar kemugkinan pemda tersebut melakukan pengungkapan sukarela dengan metode grafik.

Penelitian ini mengacu kepada penelitian yang dilakukan oleh Permadi (2017) yang meneliti faktor-faktor yang mempengaruhi tingkat pengungkapan Laporan Keuangan Pemerintah Daerah. Selain itu, juga mengacu pada penelitian yang dilakukan oleh Supriyanto dan Purbohudono (2015) yang meneliti tentang Voluntary Graphics Disclosure pada Pemerintah Kabupaten/Kota di Indonesia. Penelitian ini mencoba untuk mengetahui faktor-faktor yang mempengaruhi praktik voluntary graphics disclosure pada LKPD di kabupaten/kota di Indonesia pada tahun 2017. Penelitian ini memutuskan mengembangkan penelitian terdahulu tersebut dengan beberapa perbedaan diantaranya menggunakan tahun laporan keuangan 2017 untuk melihat bagaimana perkembangan voluntary graphics disclosure tersebut dimasa sekarang, menambah jumlah populasi dan sampel, menggabungkan serta menguji beberapa variabel yang diadopsi dari beberapa penelitian sebelumnya.

Penelitian ini menarik dilakukan karena masih sedikitnya penelitian mengenai topik pengungkapan sukarela laporan keuangan di sektor pemerintah khususnya yang menggunakan metode grafik, akibat terbatasnya informasi dan data dari pemerintah yang sulit diakses publik, dan cenderung rahasia. Selain itu, dapat menjadi wujud tolak ukur dan bentuk evaluasi atas pengungkapan sukarela yang dilakukan pemerintah daerah sehingga harapan adanya pemberian reward bagi yang melakukannya sebagai upaya perbaikan laporan keuangan pemerintah. Penelitian ini juga diharapkan mampu memberi kontribusi kepada masyarakat yang 
membutuhkan informasi dan sadar akan kebutuhan akuntabilitas dan transparansi melalui bentuk penilaian dan evaluasi atas pengungkapan wajib yang dilakukan pemerintah daerah.

Tujuan dari penelitian ini untuk memberikan bukti empiris mengenai pengaruh kinerja pemda, tingkat ketergantungan pemda, lokasi pemda dan kekayaan pemda terhadap voluntary graphics disclosure pada pemerintah kabupaten/kota di Indonesia tahun 2017.

\section{REVIU LITERATUR DAN HIPOTESIS}

\section{Teori Agensi (Agency Theory)}

Jensen dan Meckling (1976) menjelaskan teori agensi terjadi karena adanya hubungan kontraktual antara 2 pihak yaitu principal dan agent. Pihak principal selaku pemilik sumber daya melimpahkan wewenang kepada agent selaku pengendali dan pengguna sumber daya untuk mencapai kepentingan bersama. Implikasi teori keagenan tidak hanya dalam lingkupan organisasi sektor swasta, namun juga sektor publik, khususnya pemerintahan. Teori agensi pada sektor publik memandang bahwa pemerintah sebagai agent bisa saja bertindak sesuai kepentingan mereka sendiri karena memiliki informasi lebih. Sehingga pemerintah dituntut untuk transparan terhadap masyarakat (principals).

Ketidakmampuan pemerintah untuk mengoptimalkan kepentingan masyarakat luas disebut dengan masalah agensi (agency problem). Masalah agensi ini bisa disebabkan oleh konflik kepentingan (conflict of interest) maupun asimetri informasi (information asymmetry). Supriyanto dan Probohudono (2015) menyatakan hal yang dapat dilakukan untuk meminimalisir terjadinya asimetri informasi adalah dengan melakukan pengungkapan atas informasi dalam laporan keuangan sebagai pengawasan pada perilaku pemerintah serta untuk menyelaraskan tujuan masyarakat dan pemerintah. Masyarakat menginginkan agar terjaganya akuntabilitas dan transparansi pemerintah dikalangan masyarakat maka diperlukan pengungkapan informasi yang akan menimbulkan kepercayaan masyarakat selaku principals terhadap agents yaitu pemerintah

\section{Teori Sinyal (Signalling Theory)}

Spence (1973) menyatakan bahwa teori sinyal menjelaskan bagaimana pihak principal dan agent mengatasi asimetri informasi dalam suatu perjanjian atau hubungan kontraktual. Pihak agent memberikan sinyal kepada principal tentang hal menarik yang dapat ditawarkan dalam rangka mengurangi asimetri informasi dan mengembangkan kesempatan untuk mendorong principal melakukan suatu pertukaran. Adhi (2012), Liza \& Arza (2019) menjelaskan bahwa salah satu bentuk sinyal dari pemerintah daerah dapat berupa pengungkapan yang bersifat sukarela. Pengungkapan informasi yang transparan dapat dikatakan sebagai sinyal-sinyal dari principal kepada agent yang dapat berpengaruh terhadap keputusan yang akan diambil.

\section{Laporan Keuangan Pemerintah Daerah}

Peraturan Pemerintah Nomor 71 Tahun 2010 tentang Standar Akuntansi Pemerintahan (SAP) mendefenisikan laporan keuangan sebagai laporan terstruktur mengenai posisi keuangan dan transaksi yang dilakukan oleh suatu entitas pelaporan serta entitas tersebut wajib menyampaikan laporan pertanggungjawaban berupa laporan keuangan. Tujuan umum pelaporan keuangan adalah untuk memberikan informasi mengenai posisi keuangan, kinerja, dan arus kas suatu entitas yang berguna bagi sejumlah besar pemakai (wide range users) guna mencapai tujuannya.

Penyataan Standar Akuntansi Pemerintah (PSAP) No. 1 menjelaskan LKPD terdiri atas Laporan Arus Kas, Laporan Realisasi Anggaran, Neraca, Laporan Operasional, Laporan Perubahan Saldo Anggaran Lebih, Laporan Perubahan Ekuitas, dan Catatan atas Laporan 
Keuangan. Menurut Bastian (2010) laporan keuangan harus memenuhi empat dasar karakteristik kualitatif yaitu dapat dipahami, relevan, andal dan dapat dibandingkan.

\section{Pengungkapan Sukarela Berbasis Grafik (Graphical Voluntary Disclosure)}

Suwardjono (2005:578) mendefinisikan pengungkapan (disclosure) sebagai bagian integral dari pelaporan keuangan. Pengungkapan merupakan bagian yang tak terpisahkan dari pelaporan keuangan. Pengungkapan dalam laporan keuangan dapat dikelompokkan menjadi dua, yaitu pengungkapan wajib (mandatory disclosure) dan pengungkapan sukarela (voluntary disclosure) (Kieso, Weygandt, \& Warfield, 2010). Informasi yang ada dalam LKPD sebaiknya dapat dipahami, dapat dipercaya, relevan dan transparan, oleh karena itu dibutuhkan pengungkapan yang memadai. Pengungkapan sukarela merupakan suatu cara untuk meningkatkan transparansi dan kepercayaan publik terhadap pemerintah.

Kesulitan yang dihadapi berkaitan dengan pengkomunikasian laporan keuangan adalah pengungkapan naratif dalam laporan keuangan seringkali ditulis dalam tingkat komprehensi melebihi kapasitas pembacanya, sehingga laporan keuangan tradisional terlihat sangat kompleks dan menyebabkan information overload (Courtis, 1995). Oleh karena itu dibutuhkan penyajian informasi dengan metode grafik untuk memudahkan pengguna laporan keuangan dalam memahami informasi. Uyar (2009) menjelaskan beberapa keuntungan penggunaan grafik sebagai media untuk menyampaikan informasi perusahaan kepada pihak yang berkepentingan, diantaranya adalah grafik lebih mudah digunakan, grafik lebih muda diingat, grafik lebih menarik dan efektif dalam mengkomunikasikan informasi dan grafik dapat menyederhanakan data kualitatif yang kompleks. Jenis utama grafik diantaranya garis, bar, kolom, gambar, dan pie.

\section{Kinerja Pemerintah Daerah}

Keberhasilan sebuah organisasi sektor publik tidak dapat diukur semata-mata dari perspektif keuangan saja. Oleh karena sifat dasar yang tidak berorientasi pada profit, keberhasilan sebuah organisasi sektor publik juga harus dikukur dari kinerjanya (Nordiawan dan Hertianti, 2010:157). Kinerja merupakan hasil dari suatu organisasi yang ditujukan secara nyata dan dilakukan oleh individu yang dapat diukur. Pengukuran kinerja merupakan suatu proses sistematis untuk menilai apakah program/kegiatan yang direncanakan telah berjalan sesuai dengan semestinya. Pengukuran kinerja juga digunakan sebagai dasar untuk melakukan penilaian kinerja (Nordiawan dan Hertianti, 2010:158).

Nordiawan dan Hertianti (2010:167) mengungkapkan bahwa hal yang dapat dilakukan untuk mendorong proses pengukuran dan penilaian kinerja secara lebih sistematis, pemerintah Indonesia mempunyai sebuah pedoman penyusunan laporan kinerja yang disebut Laporan Akuntabilitas Kinerja Instansi Pemerintah (LAKIP). Kewajiban pemerintah untuk mempertanggungjawabkan kinerjanya adalah dengan menyampaikan informasi yang relevan sehubungan dengan hasil dari program yang telah dilaksanakan kepada masyarakat. . Informasi tersebut dapat berguna sebagai wujud dari bentuk akuntabilitas dan transparansi dari pemerintahan agar dapat dipercaya oleh masyarakat.

\section{Karakteristik Pemerintah Daerah}

Suhardjanto dan Yulianingtyas (2011) menjelaskan karakteristik pemerintah daerah merupakan ciri-ciri khusus yang melekat pada pemerintah daerah, menandai sebuah pemerintah daerah dan membedakannya dengan pemerintah daerah lain. Penelitian ini menggunakan karakteristik pemerintah daerah berupa tingkat ketergantungan pemda, lokasi pemda dan kekayaan pemda 
karena penelitian ini mengadopsi dari penelitian yang dilakukan oleh Supriyanto dan Probohudono (2015).

\section{Tingkat Ketergantungan Pemda}

Supriyanto dan Probohudono (2015) menyatakan bahwa tingkat ketergantungan pemda dipengaruhi oleh dana alokasi umum (DAU) yang diterima oleh pemda. Pemda yang memiliki tingkat finansial yang rendah akan menerima DAU yang lebih besar dan begitu pula sebaliknya. Pemda yang menerima DAU yang besar menunjukkan bahwa pemda tersebut tidak mandiri secara finansial sehingga tingkat ketergantungan pemda tersebut tinggi. Semakin tinggi tingkat ketergantungan pemda maka semakin kurang inovatif pemda tersebut dalam mengungkakan informasinya.

\section{Lokasi Pemerintah Daerah}

Pemda di Indonesia terbagi menjadi beberapa pulau di pulau Jawa dan di luar pulau Jawa. Menurut Abdullah (2004) lokasi pemda di Indonesia yang berbeda-beda mempengaruhi pilihan pengungkapan informasi dalam laporan keuangan. Retnoningsih (2009) menyatakan bahwa perbedaan sumber daya manusia dan kondisi ekonomi pada daerah yang terletak di pulau Jawa dan di luar jawa menyebabkan adanya perbedaan dalam hal pengungkapan informasi LKPD. Kualitas SDM yang tinggi, kualitas infrastruktur dan perekonomian yang baik menjadikan tingkat pengungkapan informasi dalam laporan keuangan pemda di Jawa lebih baik.

\section{Kekayaan Pemerintah Daerah}

Sinaga (2011) menyatakan bahwa kekayaan pemda menggambarkan tingkat kemakmuran suatu daerah. Santosa dan Rahayu (2005) menyatakan kekayaan pemda diproyeksikan dengan Pendapatan Asli Daerah (PAD) yang merupakan penerimaan dari daerahnya sendiri sehingga dapat mencerminkan tingkat kemandirian daerah tersebut. Setyaningrum dan Syafitri (2012) menyatakan bahwa sumber PAD yang utama berasal pajak dan retribusi daerah yang dari masyarakat masing-masing daerah. Apabila suatu daerah sudah berkecukupan, maka Pemda akan memiliki inisiatif untuk melakukan pengungkapan sukarela dengan metode yang mudah dipahami oleh masyarakat yaitu grafik agar laporan keuangannya transparan dan akuntabel.

\section{Pengaruh Kinerja Pemerintah Daerah terhadap Voluntary Graphics Disclosure}

Kinerja pemerintah yang baik menunjukkan bahwa pemerintah tersebut telah melaksanakan akuntabilitas dan transparansi dengan cara menyampaikan informasi yang relevan sehubungan dengan hasil kerja yang telah terlaksana kepada masyarakat. Penyampaian informasi dalam laporan keuangan dapat dilaksanakan dengan voluntary graphics disclosure atau pengungkapan informasi grafik karena semakin baik kinerja pemerintah menujukkan pemda tersebut semakin inovatif dalan menyajikan pengungkapan informasinya agar dapat dimengerti oleh seluruh kalangan masyarakat.

Penelitian yang dilakukan oleh Ali dan Saad (2006), Dilla dan Janvrin (2010), Saha dan Akter (2013) menyatakan bahwa perusahaan dengan kinerja yang baik akan menyajikan informasinya dengan metode grafik yang lebih mudah dipahami, begitu pula dengan pemerintahan. Semakin baik kinerja pemerintah maka semakin inovatif pemerintah tersebut dalam melakukan pengungkapan, seperti melaksanakan voluntary graphics disclosure.

H1: Kinerja pemerintah daerah berpengaruh positif terhadap voluntary graphics disclosure 


\section{Pengaruh Tingkat Ketergantungan Pemerintah Daerah terhadap Voluntary Graphics}

Disclosure

Tingkat ketergantungan pemda dapat dilihat melalui dana perimbangan berupa dana alokasi umum (DAU) yang diberikan kepada pemda tersebut. Pemda yang menerima DAU yang besar menunjukkan bahwa pemda tersebut tidak mandiri secara finansial dan memiliki tingkat ketergantungan yang tinggi. Penelitian sebelumnya yang dilakukan oleh Setyaningrum dan Syafitri (2012), Supriyanto dan Probohudono (2015), Hendriyani dan Tahar (2015) menunjukkan bahwa tingkat ketergantungan pemda berpengaruh negatif terhadap pengungkapan informasi dalam laporan keuangan

$\mathbf{H}_{2}$ : Tingkat ketergantungan pemda berpengaruh negatif terhadap voluntary graphics disclosure

\section{Pengaruh Lokasi Pemerintah Daerah terhadap Voluntary Graphics Disclosure}

Kesenjangan dalam segi pembangunan, perekonomian, dan fasilitas pendidikan yang terjadi antara pemda yang berada di pulau Jawa dengan pemda diluar pulau Jawa menyebabkan kualitas sumber daya manusia (SDM) di pulau Jawa lebih baik daripada diluar pulau Jawa (Retnoningsih, 2009). Oleh karena itu pengungkapan informasi pada pemda di pulau Jawa lebih memuaskan ketimbang pemda lain yang berada di luar pulau Jawa, dikarenakan baiknya kualitas SDM, infrastruktur dan perekonomian yang di dapatkan. Penelitian Supriyanto dan Probohudono (2015), Arifin et al., (2016) dan Narulitasari (2016) menyatakan bahwa pemda yang berada di pulau Jawa lebih baik dalam melakukan pengungkapan informasi dengan metode grafik daripada pemda yang berada di luar pulau Jawa.

H3: Lokasi pemda berpengaruh positif terhadap voluntary graphics disclosure

\section{Pengaruh Kekayaan Pemerintah Daerah terhadap Voluntary Graphics Disclosure}

Kekayaan pemda diproksikan dengan pendapatan asli daerah (PAD) nya. Semakin besar PAD, maka dapat dikatakan adanya partisipasi masyarakat yang besar dalam membayar pajak dan retribusi daerah, sehingga semakin besarnya kemungkinan pemda melakukan pengungkapan sukarela pada LKPD dengan metode grafik yang merupakan inovasi baru. Hal ini dimaksudkan agar tercapainya salah satu karakteristik kualitatif laporan keuangan yaitu mudah dipahami. Berdasarkan penelitian Laswad et al., (2005), Liestiani (2008), Setyaningrum dan Syafitri (2012) menyatakan bahwa kekayaan pemda memiliki pengaruh positif terhadap voluntary graphics disclosure pada laporan keuangan pemerintah daerah.

H4: Kekayaan pemda berpengaruh positif terhadap voluntary graphics disclosure

\section{Kerangka Konseptual}

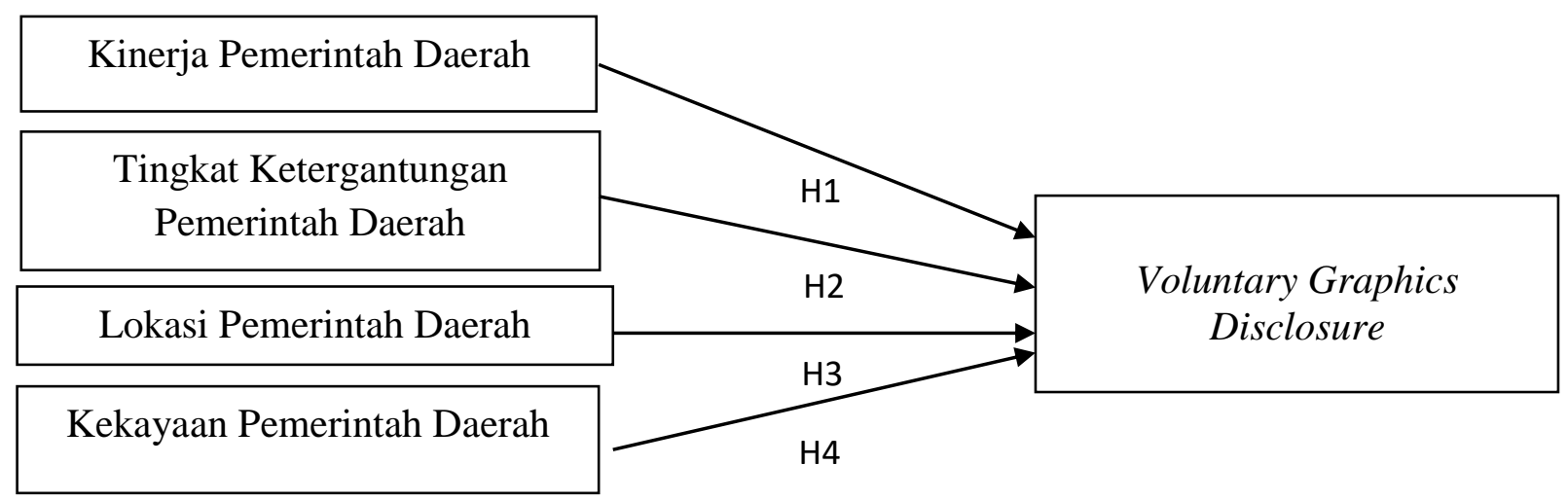

Gambar 1. Kerangka Konseptual 


\section{METODE PENELITIAN}

Jenis penelitian ini adalah penelitian kausatif. Jenis data adalah data sekunder. Penelitian ini menggunakan pendekatan kuantitatif. Data dalam penelitian ini berasal dari Laporan Hasil Pemeriksaan atas LKPD tahun 2017 yang diperoleh dari Badan Pemeriksaan Keuangan Republik Indonesia (BPK RI) untuk melihat tingkat ketergantungan pemda melalui DAU dan kekayaan pemda melalui PAD. Data kinerja pemda bersumber dari nilai hasil evaluasi Akuntabilitas Kinerja Instansi Pemerintah (AKIP) yang dikeluarkan oleh Kementrian PAN \& RB (www.evalrbkunwas.menpan.go.id). Data lokasi pemda diperoleh dari website Direktorat Jenderal Otonomi Daerah Kementerian Dalam Negeri (www.otda.kemendagri.go.id).

Populasi dalam penelitian ini adalah seluruh pemerintah daerah kabupaten/kota di Indonesia yang bejumlah 508 (lima ratus delapan) kabupaten/kota yang terdaftar pada tahun 2017, yang terdiri dari 415 pemerintah kabupaten (Pemkab) dan 93 pemerintah kota (Pemkot). Teknik pengambilan sampel dalam penelitian ini adalah menggunakan purposive sampling, dimana sampel dipilih dengan kriteria tertentu yaitu: 1) Pemda/Pemkot di Indonesia tahun 2017. 2) Pemda/Pemkot yang memiliki LKPD yang telah diaudit BPK-RI T.A. 2017. 3) Pemda/Pemkot yang menyajikan pengungkapan sukarela dengan metode grafik dalam LKPD. Penelitian dilakukan dengan menggunakan data pada tahun anggaran 2017 yang berarti sampel yang didapat adalah sebanyak 240 data. Namun, terdapat 9 data yang teridentifikasi sebagai outlier. Jadi, total sampel dalam penelitian ini adalah sebanyak 231 data. Berikut adalah tabel yang menjelaskan pengambilan sampel:

Tabel 1. Kriteria Pengambilan Sampel

\begin{tabular}{clc}
\hline No & \multicolumn{1}{c}{ Kriteria } & Jumlah \\
\hline 1 & Jumlah Pemkab/Pemkot di Indonesia tahun 2017 & 508 \\
\hline 2 & Pemda yang tidak memiliki LKPD T.A 2017 audited & $(0)$ \\
\hline 3 & Pemda yang tidak menyajikan grafik dalam LKPD T.A 2017 & $(268)$ \\
\hline 4 & Pemda sebagai outlier & $(9)$ \\
\hline & Total Sampel & $\mathbf{2 3 1}$ \\
\hline
\end{tabular}

Teknik analisis data dalam penelitian ini menggunakan model analisis regresi linier berganda. Analisis ini bertujuan untuk mengetahui apakah KINERJA, DAU, LOKASI dan WEALTH berpengaruh terhadap voluntary graphics disclosure. Model persamaan analisis regresi berganda dalam penelitian ini adalah sebagai berikut :

$$
\text { VGD }=\alpha+\beta 1 \text { KINERJA- }-\beta 2 D A U+\beta 3 L O K A S I+\beta 4 W E A L T H+e
$$

Keterangan :

$\begin{array}{ll}\text { VGD } & : \text { Voluntary Graphics Disclosure } \\ \text { KINERJA } & : \text { Kinerja Pemerintah Daerah } \\ \text { DAU } & : \text { Tingkat Ketergantungan Pemerintah Daerah } \\ \text { LOKASI } & : \text { Lokasi Pemerintah Daerah } \\ \text { WEALTH } & : \text { Kekayaan Pemerintah Daerah } \\ \alpha & : \text { Konstanta } \\ \mathrm{b}_{1} \mathrm{~b}_{2} \mathrm{~b}_{3} \mathrm{~b}_{4} & : \text { Koefesien regresi setiap variabel bebas } \\ \mathrm{e} & : \text { Standar Error }\end{array}$




\section{Variabel Penelitian \& Pengukurannya Voluntary Graphics Disclosure}

Voluntary graphics disclosure atau pengungkapan sukarela berbasis grafik diartikan sebagai penyajian informasi dimana item-item disajikan berupa item yang diungkapkan sebagai tambahan informasi bagi pengguna laporan keuangan dengan menggunakan metode terbaru yaitu grafik. Voluntary graphics disclosure pada penelitian ini diukur dengan menghitung jumlah grafik yang disajikan dalam LKPD. Pengukuran ini diadopsi dari penelitian yang dilakukan penelitian oleh Supriyanto dan Probohudono (2015).

\section{Kinerja Pemerintah Daerah}

Kinerja pada sektor pemerintahan lebih tepat jika diukur dengan kinerja non keuangan. Pengukuran kinerja pemerintah daerah dalam penelitian ini diadopsi dari penelitian yang dilakukan Supriyanto dan Probohudono (2015), dimana kinerja diukur dengan melihat nilai hasil evaluasi AKIP. Variabel kinerja dikategorikan sebagai berikut :

Tabel 2

Pengukuran Nilai Hasil Evaluasi AKIP

\begin{tabular}{clc}
\hline Nilai & \multicolumn{1}{c}{ Kategori } & Skala Pengukuran \\
\hline AA & Sangat Memuaskan & 7 \\
\hline A & Memuaskan & 6 \\
\hline BB & Sangat Baik & 5 \\
\hline B & Baik & 4 \\
\hline CC & Cukup & 3 \\
\hline C & Kurang & 2 \\
\hline D & Sangat Kurang & 1 \\
\hline
\end{tabular}

Sumber: www.evalrbkunwas.menpan.go.id, 2017

\section{Tingkat Ketergantungan Pemerintah Daerah}

Tingkat ketergantungan pemda dapat dilihat berdasarkan jumlah dana perimbangan yang diberikan oleh pemerintah pusat kepada pemda berupa Dana Alokasi Umum (DAU). Semakin besar DAU yang diterima menunjukkan pemda tersebut tidak mandiri secara finansial, yang artinya pemda tersebut memiliki tingkat ketergantungan yang tinggi. Tingkat ketergantungan pemda pada penelitian ini diukur berdasarkan adopsi dari penelitian yang dilakukan oleh Supriyanto dan Probohudono (2015), yaitu DAU dibagi dengan total realisasi pendapatan.

$$
D A U=\frac{\text { Dana Alokasi Umum }}{\text { Total Realisasi Pendapatan }}
$$

\section{Lokasi Pemerintah Daerah}

Lokasi pemerintah daerah tersebar di seluruh Indonesia dan dibagi ke dalam pemda di pulau Jawa dan pemda yang berada di luar pulau Jawa. Pengukuran variabel lokasi pemda berdasarkan adopsi dari penelitian yang dilakukan oleh Suhardjanto dan Yulianingtyas (2011) yaitu dengan skor (dummy), yaitu pemda di pulau Jawa diberi nilai 1 (satu) dan pemda di luar pulau Jawa diberi nilai 0 (nol). 


\section{Kekayaan Pemerintah Daerah}

Kekayaan pemerintah daerah dapat dilihat dari PAD yang meliputi semua penerimaan uang melalui rekening kas umum daerah, yang menambah ekuitas dana, merupakan hak daerah dalam satu tahun anggaran dan tidak perlu dibayar kembali oleh daerah. Pengukuran variabel kekayaan pemda diadopsi berdasarkan penelitian yang dilakukan oleh Liestiani (2012) yang menggunakan Pendapatan Asli Daerah (PAD) yang ditransformasikan dalam bentuk logaritma natura sebagai proksi untuk menjelaskan kekayaan daerah.

\section{HASIL DAN PEMBAHASAN \\ Analisis Statistik Deskriptif}

Analisis ini digunakan untuk menganalisis serta mendeskripsikan data berdasarkan masingmasing variabel penelitian. Analisis statistik deskriptif dapat dilihat pada tabel 3 berikut :

Tabel 3

Analisis Statistik Deskriptif

\begin{tabular}{cccccc}
\hline & $\mathrm{N}$ & Minimum & Maximum & Mean & $\begin{array}{c}\text { Std. } \\
\text { Deviation }\end{array}$ \\
\hline VGD & 231 & 1.00 & 15.00 & 4.7619 & 3.47657 \\
\hline KINERJA & 231 & 1.00 & 7.00 & 4.1126 & 2.04841 \\
\hline DAU & 231 & .04 & .70 & .4858 & .10856 \\
\hline LOKASI & 231 & .00 & 1.00 & .2771 & .44852 \\
\hline WEALTH & 231 & 22.93 & 29.27 & 25.5839 & 1.20063 \\
\hline $\begin{array}{c}\text { Valid N } \\
\text { (listwise) }\end{array}$ & 231 & & & & \\
\hline
\end{tabular}

Sumber: Data sekunder yang diolah, 2019

Hasil di atas menjelaskan variabel-variabel dalam penelitian ini. Variabel VGD (Y) memiliki rata-rata (mean) 4,7619. Nilai maksimum voluntary graphics disclosure yang disajikan dalam LKPD yaitu sebesar adalah 15.00 yang disajikan pada 3 kabupaten dan 2 kota. Nilai minimum yaitu sebesar 1.00 yang disajikan pada 28 kabupaten dan 9 kota, standar deviasi sebesar 3,47. Variabel KINERJA (X1) memiliki rata-rata sebesar 4,1126. Nilai tertinggi sebesar 7.00 yang terjadi pada 31 pemkab dan 7 pemkot, nilai terendah sebesar 1.00 yang terjadi pada 30 pemkab dan 7 pemkot. Standar deviasi variabel KINERJA adalah sebesar 2,04. Variabel DAU (X2) memiliki rata-rata sebesar 0,4858. Nilai tertinggi sebesar 0,70 dan nilai terendah sebesar 0,04 serta standar deviasi sebesar 0,10. Variabel WEALTH (X4) memiliki rata-rata sebesar 25,5839. Nilai tertinggi sebesar 29,27 dan nilai terendah sebesar 22,93 serta standar deviasi sebesar 1,20 .

\begin{tabular}{|c|c|c|c|c|c|}
\hline \multicolumn{6}{|c|}{$\begin{array}{c}\text { Tabel 4 } \\
\text { LOKASI } \\
\text { Statistik Deskrintif Variab }\end{array}$} \\
\hline \multirow{4}{*}{$\begin{array}{c}\text { Vali } \\
\mathrm{d}\end{array}$} & & $\begin{array}{c}\text { Frequenc } \\
\mathrm{y}\end{array}$ & Percent & $\begin{array}{c}\text { Valid } \\
\text { Percent }\end{array}$ & $\begin{array}{c}\text { Cumulative } \\
\text { Percent }\end{array}$ \\
\hline & Luar Pulau Jawa & 167 & 72.3 & 72.3 & 72.3 \\
\hline & Pulau Jawa & 64 & 27.7 & 27.7 & 100.0 \\
\hline & Total & 231 & 100.0 & 100.0 & \\
\hline
\end{tabular}

Sumber: Data sekunder yang diolah, 2019. 
Variabel LOKASI (X3) dengan nilai dummy 0 yaitu pada 167 Pemkab/Pemkot. Hasil ini menjelaskan bahwa terdapat 167 Pemkab/Pemkot yang dijadikan sampel dalam penelitian ini berlokasi di luar pulau Jawa (72,3\%). Sisanya dengan nilai dummy 1 sebanyak 64 Pemkab/Pemkot $(27,7 \%)$ berlokasi di pulau Jawa, standar deviasi sebesar 0,44.

\section{Uji Asumsi Klasik \\ Uji Normalitas}

Berikut tabel hasil uji normalitas menggunakan program SPSS:

Tabel 5

Uji Normalitas

One-Sample Kolmogorov-Smirnov Test

\begin{tabular}{|c|c|c|}
\hline & & Unstandardized Residual \\
\hline \multicolumn{2}{|c|}{$\mathrm{N}$} & 231 \\
\hline \multirow{2}{*}{ Normal Parameters ${ }^{\mathrm{a}, \mathrm{b}}$} & Mean & $0 \mathrm{E}-7$ \\
\hline & Std. Deviation & 3.43039871 \\
\hline \multirow{3}{*}{$\begin{array}{l}\text { Most Extreme } \\
\text { Differences }\end{array}$} & Absolute & .139 \\
\hline & Positive & .139 \\
\hline & Negative & -.095 \\
\hline \multicolumn{2}{|c|}{ Kolmogorov-Smirnov Z } & 2.113 \\
\hline \multicolumn{2}{|c|}{ Asymp. Sig. (2-tailed) } & .000 \\
\hline
\end{tabular}

a. Test distribution is Normal. b. Calculated from data.

Sumber: Data sekunder yang diolah, 2019.

Berdasarkan tabel 5 hasil uji normalitas nilai asymp Sig (2-tailed) adalah 0,000 yang mana < $\alpha=0,05$, dimana seharusnya nilai asymp Sig (2-tailed) $>\alpha=0,05$. Gujarati (2007) menyatakan bahwa asumsi normalitas mungkin tidak terlalu penting dalam set data yang besar, yaitu jumlah data yang lebih dari 30. Dalam penelitian ini obeservasi lebih dari dari 30, yaitu sebanyak 231. Sehingga, asumsi normalitas dalam penelitian ini tidaklah dipermasalahkan. Dapat disimpulkan bahwa data yang digunakan dalam penelitian ini terdistribusi normal dan model regresi yang digunakan baik, sehingga penelitian layak untuk dilanjutkan.

\section{Uji Multikolinearitas}

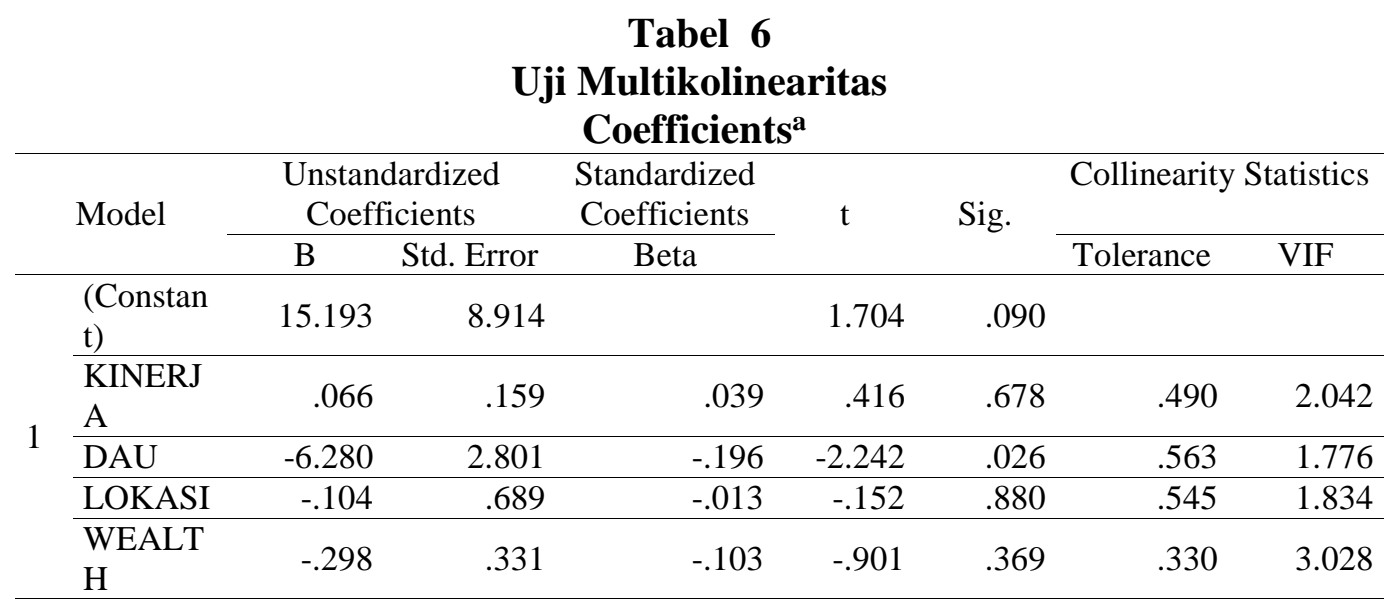

a. Dependent Variable: VGD

Sumber: Data sekunder yang diolah, 2019. 
Berdasarkan hasil uji multikolinearitas pada penelitian ini dapat dilihat bahwa setiap variabel bebas mempunyai nilai tolerance $>0,1$ dan nilai VIF $<10$. Jadi dapat disimpulkan tidak ada masalah multikoliniearitas antar variabel bebas dalam model regresi ini.

\section{Uji Autokorelasi}

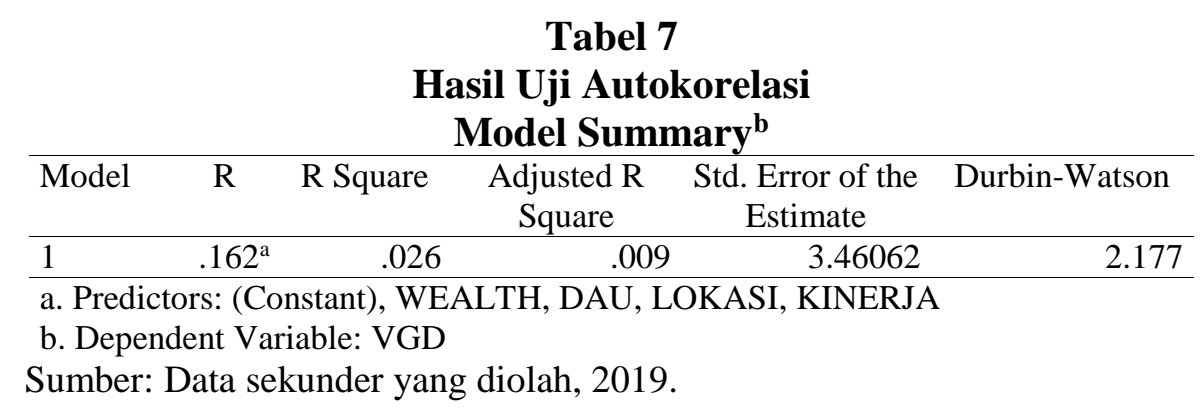

Berdasarkan hasil uji autokorelasi diatas nilai du dicari pada distribusi nilai tabel Durbin Watson berdasarkan $\mathrm{k}=4, \mathrm{~N}=231$ dengan signifikansi $\alpha=0,05$. Didapat nilai du (tabel) $=1,8104<$ DurbinWatson (hitung) $=2,177<$ nilai $(4-\mathrm{du})=2,1896$. Oleh karena itu dapat disimpulkan bahwa tidak ada gejala autokorelasi dan uji regresi linear berganda dapat dilanjutkan.

\section{Uji Heterokedastisitas}

\begin{tabular}{|c|c|c|c|c|c|c|}
\hline & & Uji & $\begin{array}{l}\text { Tabel } \\
\text { Ieteroked } \\
\text { Coefficie }\end{array}$ & $\begin{array}{l}\text { astisitas } \\
\text { ts }^{\mathrm{a}}\end{array}$ & & \\
\hline & \multirow[t]{2}{*}{ Model } & \multicolumn{2}{|c|}{$\begin{array}{l}\text { Unstandardized } \\
\text { Coefficients }\end{array}$} & \multirow{2}{*}{$\begin{array}{c}\text { Standardized } \\
\text { Coefficients } \\
\text { Beta }\end{array}$} & \multirow[t]{2}{*}{$\mathrm{t}$} & \multirow[t]{2}{*}{ Sig. } \\
\hline & & $\mathrm{B}$ & Std. Error & & & \\
\hline \multirow{5}{*}{1} & (Constant) & 9.573 & 5.135 & & 1.864 & .064 \\
\hline & KINERJA & -.099 & .092 & -.102 & -1.080 & .281 \\
\hline & DAU & -3.079 & 1.614 & -.167 & -1.908 & .058 \\
\hline & LOKASI & .252 & .397 & .057 & .635 & .526 \\
\hline & WEALTH & -.194 & .191 & -.116 & -1.017 & .310 \\
\hline
\end{tabular}

a. Dependent Variable: ABRESID

Sumber: Data sekunder yang diolah, 2019.

Berdasarkan hasil uji heterokedastisitas pada penelitian ini diperoleh nilai signifikansi atau Sig. (2-tailed) variabel KINERJA (X1) sebesar 0.281, variabel DAU (X2) sebesar 0.058, variabel LOKASI (X3) sebesar 0.526, dan variabel WEALTH (X4) sebesar 0.310. Hal ini menunjukkan nilai signifikansi lebih besar dari nilai $\alpha=0,05$ jadi dapat disimpulkan bahwa tidak terdapat masalah atau gejala heteroskedastisitas. Hal ini berarti bahwa model regresi yang dipakai untuk penelitian ini layak untuk dilanjutkan.

\section{Analisis Regresi Linear Berganda}

Berdasarkan tabel 9, didapat persamaan regresi linear berganda sebagai berikut:

VGD = 15,193 + 0,066 KINERJA - 6,280 DAU - 0,104 LOKASI - 0,298 WEALTH. 
Persamaan regresi tersebut mempunyai makna sebagai berikut:

a) Konstanta $=15,193$. Jika variabel Kinerja Pemda (KINERJA), Tingkat Ketergantungan Pemda (DAU), Lokasi Pemda (LOKASI) dan Kekayaan Pemda (WEALTH) dianggap sama dengan nol, maka variabel Voluntary Graphics Disclosure (Y) sebesar 15,193.

b) Koefisien $\mathrm{X}_{1}=0,066$. Hal ini menunjukkan jika variabel kinerja pemda meningkat satu satuan maka variabel voluntary graphics disclosure (Y) akan meningkat sebesar 0,066.

c) Koefisien $\mathrm{X}_{2}=-6,280$. Hal ini menunjukkan jika variabel tingkat ketergantungan meningkat satu satuan maka variabel voluntary graphics disclosure (Y) akan meningkat sebesar -6,280.

d) Koefisien $X_{3}=-0,104$. Hal ini menunjukkan jika variabel lokasi pemda meningkat satu satuan maka variabel voluntary graphics disclosure (Y) akan meningkat sebesar $-0,104$

e) Koefisien $\mathrm{X}_{4}=-0,298$. Hal ini menunjukkan jika kekayaan pemda meningkat satu satuan maka variabel voluntary graphics disclosure (Y) akan meningkat sebesar -0,298.

\section{Tabel 9}

\section{Analisis Regresi Linear Berganda}

Coefficients $^{\mathbf{a}}$

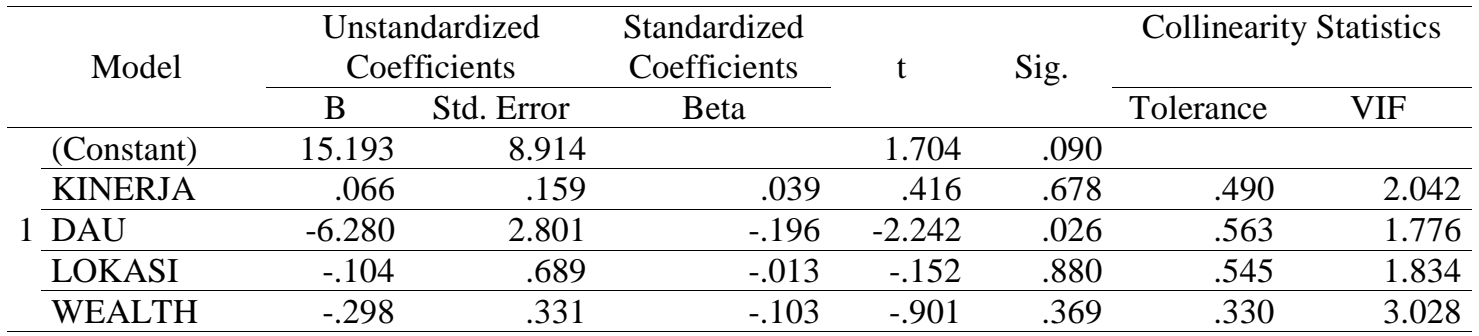

a. Dependent Variable: VGD

Sumber: Data sekunder yang diolah, 2019.

\section{Uji Hipotesis}

\section{Uji Koefisien Determinasi (Adjusted $\boldsymbol{R}^{2}$ )}

\section{Tabel 10}

\section{Hasil Uji Koefisien Determinasi (Adjusted $R^{2}$ )}

Model Summaryb

\begin{tabular}{lccccr}
\hline Model & $\mathrm{R}$ & R Square & $\begin{array}{c}\text { Adjusted R } \\
\text { Square }\end{array}$ & $\begin{array}{c}\text { Std. Error of the } \\
\text { Estimate }\end{array}$ & Durbin-Watson \\
\hline 1 & $.162^{\mathrm{a}}$ & .026 & .009 & 3.46062 & 2.177 \\
\hline $\begin{array}{l}\text { a. Predictors: (Constant), WEALTH, DAU, LOKASI, KINERJA } \\
\text { b. Dependent Variable: VGD }\end{array}$ & & & \\
\end{tabular}

Sumber: Data sekunder yang diolah, 2019.

Dari tabel di atas didapat nilai Adjusted $R^{2}$ sebesar 0,009. Hal ini menunjukkan bahwa kontribusi variabel kinerja pemda (X1), tingkat ketergantungan pemda (X2) dan lokasi pemda (X3) dan kekayaan pemda terhadap voluntary graphics disclosure (Y) sebesar 0,9\%. Berarti $0,9 \%$ faktor yang berpengaruh terhadap voluntary graphics disclosure dapat dijelaskan oleh kinerja pemda, tingkat ketergantungan pemda, lokasi pemda dan kekayaan pemda. Sisanya sebesar 99,1\% lagi dipengaruhi oleh faktor lain yang tidak terdapat pada penelitian ini. 


\section{Uji Koefisien Regresi Parsial (Uji t)}

Hasil uji statistik T pada variabel Y dapat dilihat dari tabel 10 bahwa pada pada variabel kinerja pemda $(\mathrm{X} 1)$ diperoleh nilai $\mathrm{t}_{\text {hitung }}=0,416<1,65=\mathrm{t}_{\text {tabel }}$ dan $\operatorname{sig}=0,678>0,05 \%$ jadi $\mathrm{H}_{0}$ diterima. Ini berarti variabel kinerja pemda secara statistik tidak berpengaruh terhadap variabel voluntary graphics disclosure (Y). Pada variabel tingkat ketergantungan pemda (X2) diperoleh nilai $t_{\text {hitung }}=-2,242$ dengan nilai sig $=0,026<0,05$ jadi $\mathrm{H}_{0}$ ditolak dan $\mathrm{H}_{\mathrm{a}}$ diterima, ini berarti variabel tingkat ketergantungan pemda secara statistik berpengaruh negatif terhadap variabel voluntary graphics disclosure $(\mathrm{Y})$. Pada variabel lokasi pemda $(\mathrm{X} 3)$ diperoleh nilai $\mathrm{t}_{\text {hitung }}=$ $0,152<1,65=\mathrm{t}_{\text {tabel }}$ dan sig $=0,880>0,05$ jadi $\mathrm{H}_{0}$ diterima. Ini berarti variabel lokasi pemda secara statistik tidak berpengaruh terhadap variabel voluntary graphics disclosure (Y). Pada variabel kekayaan pemda $(\mathrm{X} 4)$ diperoleh nilai $\mathrm{t}_{\text {hitung }}=-0,901<1,65=\mathrm{t}_{\text {tabel }}$ dan $\mathrm{sig}=0,369>0,05$ jadi $\mathrm{H}_{0}$ diterima. Ini berarti variabel kekayaan pemda secara statistik tidak berpengaruh terhadap variabel voluntary graphics disclosure (Y).

Tabel 11

Hasil Uji Parsial (Uji Statistik T)

Coefficients $^{\mathbf{a}}$

\begin{tabular}{|c|c|c|c|c|c|c|c|c|}
\hline \multirow{3}{*}{\multicolumn{2}{|c|}{ Model }} & \multirow{2}{*}{\multicolumn{2}{|c|}{$\begin{array}{c}\text { Unstandardized } \\
\text { Coefficients }\end{array}$}} & \multirow{3}{*}{$\begin{array}{c}\begin{array}{c}\text { Standardized } \\
\text { Coefficients }\end{array} \\
\text { Beta } \\
\end{array}$} & \multirow{3}{*}{$\mathrm{t}$} & \multirow{3}{*}{ Sig. } & \multicolumn{2}{|c|}{ Collinearity Statistics } \\
\hline & & & & & & & & \\
\hline & & $\mathrm{B}$ & Std. Error & & & & Tolerance & VIF \\
\hline & (Constant) & 15.193 & 8.914 & & 1.704 & .090 & & \\
\hline & KINERJA & .066 & .159 & .039 & .416 & .678 & .490 & 2.042 \\
\hline 1 & DAU & -6.280 & 2.801 & -.196 & -2.242 & .026 & .563 & 1.776 \\
\hline & LOKASI & -.104 & .689 & -.013 & -.152 & .880 & .545 & 1.834 \\
\hline & WEALTH & -.298 & .331 & -.103 & -.901 & .369 & .330 & 3.028 \\
\hline
\end{tabular}

a. Dependent Variable: VGD

Sumber: Data sekunder yang diolah, 2019.

\section{Uji Koefisien Regresi Simultan (Uji f)}

Tabel 12

Hasil Uji F

ANOVA $^{\mathrm{a}}$

\begin{tabular}{lrrrrr}
\hline Model & $\begin{array}{l}\text { Sum of } \\
\text { Squares }\end{array}$ & Df & $\begin{array}{c}\text { Mean } \\
\text { Square }\end{array}$ & F & Sig. \\
\hline Regression & 73.349 & 4 & 18.337 & 1.531 & $.194^{\mathrm{b}}$ \\
\cline { 2 - 6 } & 2706.556 & 226 & 11.976 & & \\
\hline Residual & 2779.905 & 230 & & & \\
\hline
\end{tabular}

a. Dependent Variable: VGD

b. Predictors: (Constant), WEALTH, DAU, LOKASI, KINERJA

Sumber: Data sekunder yang diolah, 2019.

Berdasarkan tabel 11 di atas dapat dilihat nilai sig. yang diperoleh sebesar 0,194 yang mana > 0,05. Maka dapat disimpulkan bahwa variabel independen yaitu kinerja pemda, tingkat ketergantungan pemda, lokasi pemda dan kekayaan pemda secara bersama-sama tidak berpengaruh signifikan terhadap variabel dependen yaitu voluntary graphics disclosure. 


\section{Pembahasan \\ Pengaruh Kinerja Pemda terhadap Voluntary Graphics Disclosure}

Berdasarkan hasil penelitian pada pemerintah daerah kabupaten/kota di Indonesia pada tahun 2017 yang telah dilakukan, hasil uji signifikansi parsial atau uji statistik T diperoleh keterangan bahwa H1 ditolak yang berarti bahwa variabel kinerja pemerintah daerah tidak berpengaruh terhadap voluntary graphics disclosure. Hal ini dapat dilihat pada nilai tabel analisis regresi linear berganda yang menunjukkan variabel KINERJA (X1) memiliki nilai sig. sebesar 0,678 yang mana $>\alpha=0,05$.

Pemda yang memiliki nilai evaluasi AKIP yang baik menunjukkan bahwa pemda tersebut memiliki kinerja yang akuntabel. Berdasarkan hasil penelitian ini ditemukan bahwa pemda dengan nilai hasil evaluasi AKIP yang baik, belum tentu akan menyajikan informasi dalam LKPD dalam bentuk grafik yang lebih banyak. Hal tersebut dikarenakan antara dokumen LAKIP dan LKPD merupakan dua jenis laporan pertanggungjawaban yang berbeda, kedua laporan tersebut dihasilkan oleh sistem akuntansi yang berbeda. Hal ini menyebabkan kinerja pemerintah daerah tidak berpengaruh positif terhadap voluntary graphics disclosure.

Hasil penelitian ini didukung oleh penelitian Supriyanto dan Probohudono (2015) yang melakukan penelitian mengenai Faktor-Faktor yang Mempengaruhi Praktik Voluntary Graphics Disclosure Pada Pemerintah Kabupaten/Kota di Indonesia. Hasil penelitiannya menyebutkan bahwa kinerja pemda tidak berpengaruh terhadap voluntary graphics disclosure. Selain itu hasil penelitian ini juga sejalan dengan penelitian oleh Guddal (2016) yang menyatakan bahwa kinerja organisasi tidak berpengaruh terhadap pengungkapan informasi sukarela berbasis grafik dalam annual report. Sedangkan hasil penelitian ini tidak sejalan dengan penelitian Saha \& Akter (2013) yang meneliti tentang hubungan kinerja perusahaan dengan pengungkapan sukarela dengan metode grafik. Organisasi dengan kinerja yang lebih baik akan lebih menggunakan grafik dalam pengungkapan informasi laporan tahunan mereka. Hasil penelitian ini juga tidak sejalan dengan penelitian Ali \& Saad (2006) serta penelitian Dilla \& Janvrin (2010).

Berdasarkan penjelasan di atas, penyebab kinerja pemerintah daerah tidak berpengaruh terhadap voluntary graphics disclosure adalah karena kedua laporan tersebut dikeluarkan oleh dua instansi yang berbeda, tidak terdapat korelasi antara opini audit BPK-RI atas Laporan Keuangan Pemerintah Daerah dan nilai hasil evaluasi AKIP. Sehingga kinerja pemda yang tinggi tidak menjamin bahwa pemda tersebut akan menyajikan voluntary graphics disclosure pada LKPD nya. Hal tersebut dikarenakan belum terintegrasinya sistem akuntansi antara Laporan Keuangan Pemerintah Daerah dan LAKIP. Oleh karena itu, kedua dokumen yang dihasilkan tidak sejalan karena dikeluarkan oleh dua instansi yang berbeda.

\section{Pengaruh Tingkat Ketergantungan Pemda terhadap Voluntary Graphics Disclosure}

Berdasarkan hasil penelitian pada pemerintah daerah kabupaten/kota di Indonesia pada tahun 2017 yang telah dilakukan, hasil uji signifikansi parsial atau uji statistik T diperoleh keterangan bahwa $\mathrm{H} 2$ diterima yang berarti bahwa variabel tingkat ketergantungan pemda terbukti berpengaruh negatif terhadap voluntary graphics disclosure. Hal ini dapat dilihat dari nilai tabel analisis regresi linear berganda yang menunjukkan variabel DAU (X2) memiliki nilai sig. sebesar 0,026 yang mana $<\alpha=0,05$.

Hasil tersebut menjelaskan bahwa semakin besar tingkat ketergantungan pemda kepada pemerintah pusat, maka semakin sedikit pemda mengungkapkan informasi dengan menggunakan metode grafik dalam LKPD. Hal tersebut disebabkan karena pemda yang menerima DAU dalam jumlah besar mengindikasikan bahwa pemda tersebut tidak mandiri secara keuangan, sehingga 
tidak mampu melakukan inovasi. Pengungkapan informasi dengan grafik merupakan salah satu inovasi dalam pelaporan keuangan. Selain itu, hal yang menyebabkan hubungan negatif antara DAU dengan voluntary graphics disclosure adalah mekanisme pelaporan DAU. Menurut UU tentang Perimbangan Keuangan antara Pemerintah Pusat dan Pemda disebutkan bahwa DAU dilaporkan satu paket dalam LKPD. Pelaksanaan DAU dilaporkan kepada DPRD, bukan kepada pemerintah pusat selaku pemberi dana, sehingga tidak ada tekanan dari pemberi dana kepada pemda untuk melaporkan penggunaan DAU secara transparan dan akuntabel. Mekanisme pelaporan DAU ini berbeda dengan kewajiban pelaporan atas dana perimbangan yang lain, yaitu Dana Konsentrasi dan Tugas Pembantuan.

Hasil penelitian ini didukung oleh penelitian yang dilakukan oleh Setyaningrum dan Syafitri, 2012 yang meneliti tentang Analisis Pengaruh Karakteristik Pemerintah Daerah Terhadap Tingkat Pengungkapan Laporan Keuangan yang menyimpulkan bahwa tingkat ketergantungan pemda berpengaruh negatif terhadap tingkat pengungkapan informasi grafik dalam LKPD. Selain itu penelitian ini sejalan dengan penelitian oleh Supriyanto dan Probohudono (2015) mengenai Faktor-Faktor yang Mempengaruhi Praktik Voluntary Graphics Disclosure Pada Pemerintah Kabupaten/Kota di Indonesia. Sedangkan hasil penelitian ini tidak sejalan dengan penelitian Suhardjanto dan Susilo (2015) yang menyatakan bahwa tingkat ketergantungan memiliki pengaruh signifikan positif terhadap pegungkapan sukarela dalam laporan keuangan. Hal ini bisa dikarenakan adanya ketergantungan yang besar memungkinkan pemerintah pusat untuk meminta pengungkapan yang lebih lengkap pada pemda untuk memonitor pemda tersebut.

Jadi dapat disimpulkan penyebab tingkat ketergantungan pemda berpengaruh signifikan negatif terhadap voluntary graphics disclosure yaitu pemda yang menerima DAU yang tinggi menunjukkan bahwa pemda tersebut tidak mandiri secara finansial. Hal tersebut menyebabkan pemda tersebut tidak memiliki inovasi untuk mengungkapkan informasi laporan keuangannya sehingga tidak dapat melaksanakan voluntary graphics disclosure. Selain itu mekanisme pelaporan DAU yang dilaporkan dalam LKPD, bukan kepada pemerintah pusat selaku pemberi dana, sehingga tidak ada tekanan dari pemerintah pusat kepada pemda untuk melaporkan penggunaan DAU secara transparan dan akuntabel.

\section{Pengaruh Lokasi Pemda terhadap Voluntary Graphics Disclosure}

Berdasarkan hasil penelitian pada pemerintah daerah kabupaten/kota di Indonesia pada tahun 2017 yang telah dilakukan, hasil uji signifikansi parsial atau uji statistik T diperoleh keterangan bahwa H3 ditolak yang berarti bahwa variabel lokasi pemerintah daerah tidak terbukti berpengaruh terhadap voluntary graphics disclosure. Hal ini dapat dilihat pada nilai tabel analisis regresi linear berganda yang menunjukkan variabel LOKASI (X3) memiliki nilai sig. sebesar 0,880 yang mana $>\alpha=0,05$.

Secara umum, baik pemda yang berada di Pulau Jawa maupun pemda yang berada di luar pulau Jawa memiliki wewenang yang sama yaitu mengurus pemerintahannya sendiri. Saat ini kedudukan pemerintah daerah adalah sama / sejajar yaitu dibawah provinsi atau disebut dengan daerah tingkat II. Lokasi pemda tidak berpengaruh terhadap pelaksanaan voluntary graphics disclosure karena pemda di Indonesia keseluruhannya sudah menjalankan Standar Akuntansi Pemerintah (SAP) yang merupakan peraturan baru yang dikeluarkan dan dilaksanakan serempak di seluruh Indonesia, sehingga tingkat pemahaman setiap pemda di Indonesia tentang SAP adalah sama. Hal ini menunjukkan bahwa walaupun lokasi pemda tersebut berada di luar pulau jawa, bukan berarti pemda tersebut tertinggal dari pemda-pemda yang berada di pulau Jawa dan 
tidak bisa mengungkapkan informasi dengan metode grafik atau dengan kata lain tidak menjalankan voluntary graphics disclosure.

Penelitian ini sejalan dengan penelitian yang dilakukan oleh Suhardjanto \& Yulianingtyas (2011) yang melakukan penelitian tentang Pengaruh Karakteristik Pemerintah Daerah Terhadap Voluntary Graphics Disclosure dalam LKPD. Hasil penelitian ini menyimpulkan bahwa lokasi pemerintah daerah tidak berpengaruh terhadap pengungkapan informasi dengan metode grafik yang dilakukan oleh pemda tersebut. Sedangkan hasil penelitian ini tidak sejalan dengan penelitian Supriyanto dan Probohudono yang menyimpulkan bahwa lokasi pemda berpengaruh positif dengan voluntary graphics disclosure. Hal ini disebabkan karena faktor kualitas pendidikan, kondisi perekonomian, dan SDM yang lebih unggul sehingga pemda di Pulau Jawa lebih baik dalam menyajikan informasi di LKPD daripada pemda di luar pulau Jawa.

Berdasarkan pemaparan di atas, dapat disimpulkan penyebab lokasi pemda tidak berpengaruh terhadap voluntary graphics disclosure yaitu karena kedudukan pemda dan pemkot adalah sama yaitu daerah tingkat II yang berada dibawah provinsi. Selain itu pemda di seluruh Indonesia sudah menerapkan SAP secara serempak sehingga pemahaman tentang SAP di pemda adalah sama tanpa memperdulikan lokasi pemda tersebut, walaupun pemda tersebut berada di luar pulau jawa hal itu tidak akan mempengaruhi penyajian informasi dengan grafik pada LKPD.

\section{Pengaruh Kekayaan Pemda terhadap Voluntary Graphics Disclosure}

Berdasarkan hasil penelitian pada pemerintah daerah kabupaten/kota di Indonesia pada tahun 2017 yang telah dilakukan, hasil uji signifikansi parsial atau uji statistik T diperoleh keterangan bahwa H4 ditolak yang berarti bahwa variabel kekayaan pemerintah daerah tidak terbukti berpengaruh terhadap voluntary graphics disclosure. Hal ini dapat dilihat pada nilai tabel analisis regresi linear berganda yang menunjukkan variabel WEALTH (X4) memiliki nilai sig. sebesar 0,369 yang mana $>\alpha=0,05$.

Pemda dengan PAD yang tinggi, belum tentu akan menyajikan informasi dalam LKPD dalam bentuk grafik yang lebih banyak. Hal tersebut dikarenakan masih rendahnya tingkat kepedulian masyarakat atas pajak dan retribusi yang dibayarkan. Masyarakat cenderung hanya melaksanakan kewajiban tanpa menuntut hak. Peran principal dan agents antara pemerintah daerah dengan masyarakat kurang dapat terlaksana dengan baik, akibatnya peran PAD kurang bisa memotivasi dan menyadarkan pemerintah dalam melakukan pengungkapan grafik dengan metode yang lebih baik.

Penelitian ini sejalan dengan penelitian yang dilakukan oleh Permadi (2017) yang melakukan penelitian tentang Faktor - Faktor yang Mempengaruhi Pengungkapan Laporan Keuangan Pemerintah Daerah. Hasil penelitian ini menyimpulkan bahwa kekayaan pemerintah daerah tidak berpengaruh terhadap pengungkapan informasi dalam LKPD yang dilakukan oleh pemda tersebut. Sedangkan hasil penelitian ini tidak sejalan dengan penelitian Laswad et al., (2005), Liestiani (2008) serta Setyaningrum dan Syafitri (2012) yang menyimpulkan bahwa kekayaan pemda memiliki pengaruh positif dan signifikan terhadap pengungkapan informasi dalam LKPD. Hal ini disebabkan oleh tingginya partisipasi masyarakat dalam membayar pajak dan retribusi daerah, sehingga Pemda akan terdorong untuk melakukan pengungkapan secara lengkap pada laporan keuangannya agar transparan dan akuntabel.

Berdasarkan pemaparan di atas, dapat disimpulkan penyebab kekayaan pemda tidak berpengaruh terhadap voluntary graphics disclosure yaitu karena kurangnya pengetahuan masyarakat mengenai hak dan kewajibannya sebagai warga Negara. Masyarakat kebanyakan hanya mengetahui mengenai kewajiban mereka untuk membayar retribusi dan pajak, sementara 
banyak masyarakat melupakan hak mereka sebagai pembayar pajak yaitu untuk memperoleh transparansi dan akuntabilitas. Masyarakat kurang menuntut pemerintah selaku principal untuk melakukan pengungkapan informasi dalam LKPD. Sehingga pemda yang memiliki PAD yang tinggi belum tentu akan melaksanakan voluntary graphics disclosure sebab masih kurangnya tekanan oleh pihak agents.

\section{SIMPULAN, KETERBATASAN, DAN SARAN \\ Simpulan}

Berdasarkan hasil temuan penelitian dan pengujian hipotesis yang diajukan sebelumnya dapat disimpulkan bahwa:

1. Hipotesis pertama tidak terdukung dalam penelitian ini yang mana hasil penelitian menunjukkan bahwa variabel kinerja pemerintah daerah (X1) tidak berpengaruh positif terhadap voluntary graphics disclosure.

2. Hipotesis kedua terdukung dalam penelitian ini yang mana hasil penelitian menunjukkan bahwa variabel tingkat ketergantungan pemda (X2) berpengaruh negatif terhadap voluntary graphics disclosure.

3. Hipotesis ketiga tidak terdukung dalam penelitian ini yang mana hasil penelitian menunjukkan bahwa variabel lokasi pemerintah daerah (X3) tidak berpengaruh positif terhadap voluntary graphics disclosure.

4. Hipotesis keempat tidak terdukung dalam penelitian ini yang mana hasil penelitian menunjukkan bahwa variabel kekayaan pemerintah daerah (X4) tidak berpengaruh positif terhadap voluntary graphics disclosure.

\section{Keterbatasan}

Penelitian ini telah dirancang dan direncanakan dengan sebaik-baiknya, namun peneliti menyadari masih terdapat beberapa keterbatasan dalam penelitian ini yaitu:

1. Penelitian ini hanya dilakukan dengan data tahun 2017, hal ini menyebabkan hasil penelitian mungkin berbeda dengan tahun yang terbaru.

2. Kemampuan variabel independen yang dilakukan pada penelitian ini masih rendah dalam menjelaskan pengaruhnya terhadap variabel dependen.

3. Penelitian ini hanya menggunakan data sekunder yang ada pada Laporan Hasil Pemeriksaan (LHP) atas Laporan Keuangan Pemerintah Daerah (LKPD) yang periksa oleh Badan Pemeriksa Keuangan (BPK).

\section{Saran}

Berdasarkan pembahasan dan kesimpulan yang terdapat dalam penelitian ini, maka peneliti mengajukan beberapa saran sebagai berikut:

\section{Bagi Pemerintah Daerah}

Diharapkan pemerintah daerah lebih memperhatikan metode pegungkapan informasi yang lebih inovatif pada LKPD seperti menggunakan metode grafik (voluntary graphics disclosure) ini.

\section{Bagi Penelitian Selanjutnya}

Diharapkan penelitian selanjutnya lebih dapat memaksimalkan penelitian dengan menambah faktor-faktor lain yang diduga dapat mempengaruhi Voluntary Graphics Disclosure seperti 
karakteristik Kepala Daerah. Penelitian selanjutnya juga diharapkan dapat menambah sumber data yang digunakan maupun waktu dari penelitian agar mendapatkan hasil yang lebih maksimal dan akurat.

\section{DAFTAR PUSTAKA}

Abdullah, M. F. (2004). Dasar-Dasar Manajemen Keuangan, Cetakan Keempat. Penerbit Universitas Muhammadiyah. Malang

Adhi, N. (2012). Pengaruh Karakteristik Perusahaan Terhadap Luas Pengungkapan Sukarela Dan Implikasinya Terhadap Asimetri Informasi. Skripsi. Universitas Diponegoro

Ali, A. M., dan Saad, R. A. J. (2006). Impression management: the case of Malaysian financial graphs. International Journal of Management Studies (IJMS), 13(2), 41-74.

Arifin, J., Tower, G., \& Porter, S. (2016). Finacial Reporting Compliance in Indonesian Local Governments: Mimetic Pressure Dominates. JAAI, 19(1), 68-84.

Bastian, I. (2001). Akuntansi Sektor Publik di Indonesia. Edisi Pertama. Yogyakarta: BPFE

Bastian, I. (2010). Akuntansi Sektor Publik: Suatu Pengantar. Jakarta: Salemba Empat

Beattie, V., \& Jones, M. (1994). An Empirical Study of Graphical Format Choices in Charity Annual Reports. Financial Accountability \& Management, 10 (3), 215-236.

Beattie, V., \& Jones, M. J. (2002). Measurement Distortion of Graphs in Corporate Reports: an Experimental Study. Accounting, Auditing \& Accountability Journal, 15(4), 546-564.

Beattie, V., dan Jones, M. J. (1997). A Comparative Study of the Use of Financial Graph in the Corporate Annual Reports of Major U.S. and U.K. Companies. Journal of International Financial Management and Accounting, 8(1), 33-68

Diamond, J. (2002). Performance Budgeting-Is Accrual Accounting Required? IMF Working Paper. Fiscal Affairs Department.

Dilla, W. N., dan Janvrin, D. J. (2010). The Incidence and Quality of Graphics in Annual Reports: An International Comparison. Accounting Horizons, 24(2), 257- 278.

Fulkerson, C. L., Pitman, M. K., dan Frownfelter-Lohrke, C. (1999). Preparing Financial Graphics: Principles to Make Your Presentations More Effective. The CPA Journal, 69(6), 28-33.

Ghozali, I. (2009). Aplikasi Analisis Multivariate dengan Program SPSS, Edisi. Keempat. Penerbit Universitas Diponegoro.

Ghozali, I. (2011). Aplikasi Analisis Multivariate dengan Program SPSS. Semarang: Badan Penerbit Universitas Diponegoro

Guddal, T. (2016). Graph Usage in Annual Reports, Evidence from Norwegian Listed Companies. A Work Project, presented as part of the requirements for the Award of a Master Degree in Management from the NOVA - School of Business and Economics, 2432.

Halim, A. (2009). Akuntansi Sektor Publik Akuntansi Keuangan Daerah, Edisi Pertama. Jakarta: Salemba Empat

Hendriyani, R. dan Tahar, A. (2015). Analisis Faktor-Faktor yang Mempengaruhi Tingkat Pengungkapan Laporan Keuangan Pemerintah Provinsi di Indonesia. Jurnal bisnis dan ekonomi (JBE), 22(1).

Herminingsih. (2009). Pengaruh Partisipasi dalam Penganggaran dan Peran Manajerial Pengelola keuangan daerah terhadap kinerja pemerintah daerah. Tesis. Universitas Diponegoro Semarang 
Hilmi. (2010). Pengaruh Kejelasan Anggaran, Pengendalian Akuntansi dan Sistem Pelaporan terhadap Kinerja Instansi Pemerintah Pada Kabupaten dan Kota di Yogyakarta. Tesis. Yogyakarta. Universitas Gajah Mada

Indriantoro, N. dan Supomo, B. (2002). Metodologi Penelitian Bisnis, Cetakan Kedua. Yogyakarta: Penerbit BFEE UGM

Jensen, M., \& Meckling, W. (1976). Theory of The Firm : Managerial Behavior, Agency Cost and Ownership Structure. Journal of Financial Economics 3, 305-360.

Kawedar, W., dkk. (2008). Akuntansi Sektor Publik (Pendekatan Penganggaran Daerah dan Akuntansi Keuangan Daerah), Buku 1. Semarang: Salemba Empat

Khomsiyah. (2003). Hubungan Corporate Governance dan Pengungkapan Informasi: Pengujian Secara Simultan”. Simposium Nasional Akuntansi VI. Surabaya.

Kieso, D. E., Weygandt, J. J., \& Warfield, T. D. (2010). Intermediate Accounting IFRS Edition. New York: John Wiley \& Sons. Inc.

Krishnan, J. (2005). Audit committee quality and internal control: An empirical analysis. The Accounting Review, 80(2), 649-675.

Lasward, F., Fisher, R., dan Oyelere, P. (2005). Determinant of Voluntary Internet Financial Reporting by Local Government Authorities. Journal of Accounting and Public Policy.

Liestiani, A. (2008). Pengungkapan Laporan Keuangan Pemda Kabupaten/Kota di Indonesia Untuk Tahun Anggaran 2006. Skripsi. Fakultas Ekonomi Universitas Indonesia, Depok.

Liza, W. J., \& Arza, F. I. (2019). Analisis Faktor-Faktor Yang Mempengaruhi Tingkat Pengungkapan Sukarela Laporan Keuangan Pemerintah Daerah. JURNAL EKSPLORASI AKUNTANSI, 1(3), 959-976.

Mahmudi. (2007). Analisis Laporan Keuangan Pemerintah Daerah, Yogyakarta: UPP STIM YKPN

Martani, dkk. (2014). Financial and Performance Transparency on The Local Government Websites in Indonesia. Journal of Theoretical and Applied Information Technology, 60(3).

Narulitasari, D. (2016). Pengungkapan Intellectual Capital dan Karakteristik Pemerintah Daerah Kabupaten/Kota di Indonesia. (Doctoral dissertation, UNS (Sebelas Maret University)).

Nordiawan, H. (2010). Akuntansi Sektor Publik. Edisi Kedua. Jakarta: Salemba Empat

Permadi, R. (2017). Analisis faktor-faktor yang mempengaruhi tingkat pengungkapan laporan keuangan pemerintah daerah. Skripsi, Fakultas Ekonomi dan Bisnis Universitas Islam Negeri Syarif Hidayatullah, Jakarta.

Prawirosentono, S. (2007). Manajemen Operasi, Edisi Pertama. Jakarta: Bumi Aksara

Puspita, R., dan Martani, D. (2012). Analisis pengaruh kinerja dan karakteristik PEMDA terhadap tingkat pengungkapan dan kualitas informasi dalam website PEMDA. Simposium Nasional Akuntansi XV Banjarmasin.

Republik Indonesia. (2003). Keputusan Presiden Republik Indonesia No 109 Tahun 2003 Tentang Dana Alokasi Umum Daerah Provinsi/Kabupaten/Kota. Jakarta: Pemerintah Indonesia.

Republik Indonesia. (2004). Undang-Undang Republik Indonesia No 33 Tahun 2004 Tentang Pemerintah Daerah. Jakarta: Pemerintah Indonesia.

Republik Indonesia. (2005). Peraturan Pemerintah Republik Indonesia No 24 Tahun 2005 Tentang Standar Akuntansi Pemerintah (SAP).Jakarta: Pemerintah Indonesia.

Republik Indonesia. (2006). Peraturan Pemerintah Republik Indonesia No 8 Tahun 2006 Tentang Pelaporan Keuangan dan Kinerja Instansi Pemerintah.Jakarta: Pemerintah Indonesia. 
Republik Indonesia. (2010). Undang-Undang Republik Indonesia No 71 Tahun 2010 Pernyataan Standar Akuntansi Pemerintahan.Jakarta: Pemerintah Indonesia.

Republik Indonesia. (2014). Undang-Undang Republik Indonesia No 23 Tahun 2014 Tentang Pemerintah Daerah. Jakarta: Pemerintah Indonesia.

Republik Indonesia. (2015). Undang-Undang Republik Indonesia No 9 Tahun 2015 Tentang Pemerintah Daerah. Jakarta: Pemerintah Indonesia.

Retnoningsih. (2009). Kamus Besar Bahasa Indonesia. CV Widya Karya, Semarang

Rezaee, Z., \& Porter, G. L. (1993). Can the Annual Report be Improved? Review of Business, $15(1), 38-41$.

Sadjiarto, A. (2000). Akuntabilitas dan Pengukuran Kinerja Pemerintahan. Jurnal Akuntansi dan Keuangan, 2(2), 138-150.

Saha, A. K., \& Akter, S. (2013). Corporate Governance and Voluntary Disclosure Practices of Financial and Non-Financial Sector Companies in Bangladesh. JAMAR, 11(2), 45-62.

Santosa, P. B., dan Rahayu, R. P. (2005). Analisis Pendapatan Asli Daerah Dan Faktor-Faktor yang Mempengaruhinya Dalam Upaya Pelaksanaan Otonomi Daerah di Kabupaten Kediri. Dinamika Pembangunan, 2(1).

Sekaran, U. (2013). Research Methods for Business. Chichester: John Wiley \& Son Ltd.

Setyaningrum, D., \& Syafitri, F. (2012). Analisis Pengaruh Karakteristik Pemerintah Daerah Terhadap Tingkat Pengungkapan Laporan Keuangan. Jurnal Akuntansi dan Keuangan Indonesia, 9(2).

Setyowati, L. (2016). Determinan yang Mempengaruhi Pengungkapan Laporan Keuangan Pemerintah Daerah. Esensi: Jurnal Bisnis dan Manajemen, 6(1), 45-62.

Sinaga, Y. F. (2011). Analisis Faktor-Faktor yang Mempengaruhi Pelaporan Keuangan Di Internet Secara Sukarela Oleh Pemda. Skripsi, Fakultas Ekonomi Universitas Diponegoro, Semarang

Sinaga, Y. F. (2011). Analisis Faktor-Faktor yang Mempengaruhi Pelaporan Keuangan Di Internet Secara Sukarela Oleh Pemda. Skripsi. Fakultas Ekonomi Universitas Diponegoro, Semarang.

Spence, M. (1973). Job Market Signaling. The Quarterly Journal of Economics, 87(3)

Sugiyono. (2004). Metode Penelitian. Bandung: Alfabeta

Suhardjanto, D., dan Yulianingtyas, R. R. (2011). Pengaruh Karakteristik Pemerintah Daerah terhadap Kepatuhan Pengungkapan Wajib dalam Laporan Keuangan Pemerintah Daerah (Studi Empiris pada Kabupaten/Kota di Indonesia). Jurnal Akuntansi \& Auditing, 8 (1), $30-42$.

Supriyanto dan Probohudono, A. N. (2015). Voluntary Graphics Disclosure Practices In District / City Governments In Indonesia. Simposium Nasional Akuntansi XX, Jember.

Suwardjono. (2005). Teori Akuntansi Perekayasaan Pelaporan Keuangan. Yogyakarta: BPFE.

Uyar, A. (2009). An analysis of graphic disclosure in annual reports: the case of Turkey. Managerial Auditing Journal, 24(5), 423 - 444.

www.evalrbkunwas.menpan.go.id

www.neraca.co.id

www.otda.kemendagri.go.id

Zimmerman, J. L. (1977). The Municipal Accounting Maze: An Analysis of Political Incentives. Journal of Accounting Research 